\title{
Sero-prevalence of specific Leptospira serovars in fattening pigs from 5 provinces in Vietnam
}

\author{
Hu Suk Lee ${ }^{1 *}$ (D) Nguyen Viet Khong ${ }^{2}$, Huyen Nguyen Xuan², Vuong Bui Nghia ${ }^{2}$, Hung Nguyen-Viet ${ }^{1}$ and Delia Grace ${ }^{3}$
}

\begin{abstract}
Background: Leptospirosis is a zoonotic bacterial disease with a worldwide distribution. In Vietnam, leptospirosis is considered endemic. In pigs, leptospirosis can result in reproductive problems (such as abortion and infertility) which lead to economic loss. In addition, transmission to people presents a public health risk. In Vietnam, few national studies have been conducted on sero-prevalence of leptospirosis in pigs. The main objective of this study was to evaluate the sero-prevalence and incidence of presumptive infective leptospira serovars in fattening pigs from 5 provinces in Vietnam.

Results: Blood samples from fattening pigs were randomly collected at slaughterhouses. We collected 1959 sera samples from 5 provinces (Son La, Hanoi, Nghe An, Dak Lak and An Giang) between January and early June 2016. The microscopic agglutination test (MAT) was used to identify the serogroups/serovars. Overall, the sero-prevalence was 8.17\% (95\% Cl: 6.99-9.47) and serovar Tarassovi Mitis (2.19\%) had the highest prevalence followed by Australis (1. 94\%), Javanica (1.68\%) and Autumnalis (1.17\%) using a cutoff ( $\geq 1: 100)$. The sero-prevalence among female pigs (5.28\%, 95\% Cl: 3.94-6.93) was slightly higher than among male pigs (4.88\%, 95\% Cl: 3.51-6.58), but this difference was not statistically significant.

Conclusions: Leptospirosis in pigs may be a useful indicator of the human/animal burden in Vietnam and a risk assessment tool. The presence of some of the identified serovars suggests that wildlife may play an important role in the transmission of leptospirosis to domesticated pigs in Vietnam. Therefore, strengthened monitoring and surveillance systems are needed to better understand the epidemiology of the disease and prevent or reduce infection in humans and animals.
\end{abstract}

Keywords: Leptospirosis, Vietnam, Pig, Serovar, Microscopic agglutination test (MAT)

\section{Background}

Leptospirosis is a zoonotic bacterial disease with a worldwide distribution [1-4]. It is caused by more than 250 pathogenic serovars of the genus Leptospira [5]. More than 150 mammals can be infected with Leptospira spp. Reservoir hosts include rodents, wild animals and domestic animals (such as cattle, pigs and dogs) [6-10]. Leptospira interrogans serovar Bratislava has been associated with reproductive problems in pigs (such as abortion, infertility and birth of weak piglets), which lead to

\footnotetext{
* Correspondence: H.S.Lee@cgiar.org

${ }^{1}$ International Livestock Research Institute, Regional Office for East and Southeast Asia, Room 301-302, B1 Building, Van Phuc Diplomatic Compound, 298 Kim Ma Street, Ba Dinh District, Hanoi, Vietnam

Full list of author information is available at the end of the article
}

economic loss $[11,12]$. In addition, pigs are considered to be reservoir hosts for serovars Muenchen, Pomona and Tarassovi Mitis and can also be infected with Icterohaemorrhagiae from rats, Canicola from dogs and Hardjo from cattle [13-19].

In Vietnam, leptospirosis was first identified in 1930, and the country is considered endemic with a peak during the rainy season [5, 20-22]. In 2012, a total of 241 rats were collected in the Mekong delta in Vietnam and of those, $18.3 \%$ tested positive for Leptospira serovars [19]. The identified serovars with the highest prevalence were Rattus norvegicus (33.0\%), Bandicota indica (26.5\%) and Rattus tanezumi (24.6\%). It is assumed that rats are important reservoirs of the disease. In 2002, a study conducted in the Mekong Delta found that the seroprevalence 
in sows was 73\% using a cut-off of 1:100. The serovar with the highest prevalence was Braitsalva (52\%). Although leptospirosis is a notifiable disease in humans in Vietnam, only a few cases have been reported to the centralized system. However, previous studies show that leptospirosis is a public health concern and is often responsible for $20 \%$ of acute fevers of unknown origin [22-25]. A study conducted among healthy people in the Mekong Delta identified the following positive serovars: Bataviae (21.7\%), Panama (15.2\%), Icterohaemorrhagiae (13.7\%) and Australis (8.7\%) [24].

To our knowledge, few studies have been conducted to evaluate the sero-prevalence of leptospirosis in pigs in Vietnam. Therefore, the main objective of this study was to evaluate the sero-prevalence and incidence of presumptive infective Leptospira serovars in fattening pigs from 5 provinces in Vietnam.

\section{Methods}

Blood samples from fattening pigs (6-9 months old and weighing $60-120 \mathrm{~kg}$ ) were randomly collected from the jugular vein at slaughterhouses from 5 provinces (Son La, Hanoi, Nghe An, Dak Lak and An Giang) between January and early June 2016. The selected provinces were representative of the different ecological and climatic zones in Vietnam. To evaluate the sero-prevalence of serovars in each province, the research team confirmed that all pigs sampled were raised in the respective province and not imported from other provinces.

All blood samples were immediately placed in cool boxes at slaughterhouses. Sera were extracted after centrifugation and stored at $-20{ }^{\circ} \mathrm{C}$ at local laboratories until they were transported to the National Institute of Veterinary Research (NIVR) in Hanoi for analysis. The sample size was calculated based on $50 \%$ prevalence, a precision level of 5 and 95\% confidence interval using STATA. This indicated at least 385 samples per province were to be collected using multi-stage sampling [province (5), district (25), commune (125)]. For each province, a total of 25 communes (5 communes per district) were selected from 5 districts, based on the availability of pig slaughterhouses. Within each commune, 15-16 samples were randomly collected from more than one slaughterhouse. However, we were not able to achieve the sample size in some communes due to lack of time and resources. Additional information (date of collection, sampling area and sex) was collected using a check-list.

The microscopic agglutination test (MAT) was used to identify the serogroups/serovars using two-fold serial dilutions of serum in testing, starting with 1:100 up to 1:800. Each serovar result was recorded as the highest dilution of the serum which showed at least $50 \%$ agglutination of live leptospires compared to the control sample. Positive tests were defined as MAT results $\geq 1: 100$ for at least one of the 15 serovars (Table 1). A logistic regression model was constructed with the cluster effect (by having commune as a random effect) to evaluate the association between the sex and positivity when controlling for age (6-9 months old). The logistic regression model was assessed for goodness-of-fit using the Hosmer-Lemeshow test [26]. The results were expressed as Odds ratio (OR) and $95 \%$ confidence interval (CI). An alpha level of $<0.05$

Table 1 List of Leptospira antigens used in the MAT

\begin{tabular}{|c|c|c|c|c|}
\hline No. & Genomospecies & Serogroup & Serovar & Strain \\
\hline 1 & L. interrogans & Australis & Australis & Ballico \\
\hline 2 & L. interrogans & Autumnalis & Autumnaliss & Akiyami A \\
\hline 3 & L. interrogans & Bataviae & Bataviae & Van Tienen \\
\hline 4 & L. interrogans & Canicola & Canicola & Hond Utrech IV \\
\hline 5 & L. kirschneri & Grippotyphosa & Grippotyphosa & Moskva V \\
\hline 6 & L. interrogans & Hebdomadis & Hebdomadis & Hebdomadis \\
\hline 7 & L. interrogans & Icterohaemorrhagiae & Icterohaemorrhagiae & Verdun \\
\hline 8 & L. borgpetersenii & Javanica & Javanica & Veldrat Batavia 46 \\
\hline 9 & L. noguchii & Panama & Panama & CZ214K \\
\hline 10 & L. interrogans & Pomona & Pomona & Pomona \\
\hline 11 & L. interrogans & Pyrogenes & Pyrogenes & Salinem \\
\hline 12 & L. borgpetersenii & Sejroe & Hardjo & Hardjo Bovis \\
\hline 13 & L. borgpetersenii & Sejroe & Saxkoebing & Mus 24 \\
\hline 14 & L. biflexa & Semaranga & Patoc & Patoc I \\
\hline 15 & L. borgpetersenii & Tarassovi & Tarassovi & Mitis Johnson \\
\hline
\end{tabular}

Reference: http://www.kit.nl/biomedical-research/product-category/leptospira-strains/ 
was set for statistical significance. All data were recorded in Microsoft Excel 2010 and analyzed using STATA (version 14.0, StataCorp, College Station, TX, USA). ArcGIS version 10.3.1 (ESRI, Redlands, CA, USA) was used to generate the map (Fig. 1).

\section{Results}

We collected 1959 sera samples from 5 provinces. However, seven samples from Nghe An and three samples from Son La showed hemolysis and, were discarded from the study. We detected reactions against nine different serovars. Overall, the sero-prevalence was 8.17\% (95\% CI: 6.99-9.47). Yen Chau district in Son La province had the highest sero-prevalence. Hanoi province $(9.49 \%)$ had the highest sero-prevalence whereas Dak Lak province (7.01\%) had the lowest sero-prevalence, but the differences were not statistically significant (Table 2). The most frequently detected presumptive infective serogroup was Tarassovi Mitis (2.19\%), followed by Australis (1.94\%), Javanica (1.68\%), Autumnalis (1.17\%) and Grippotyphosa

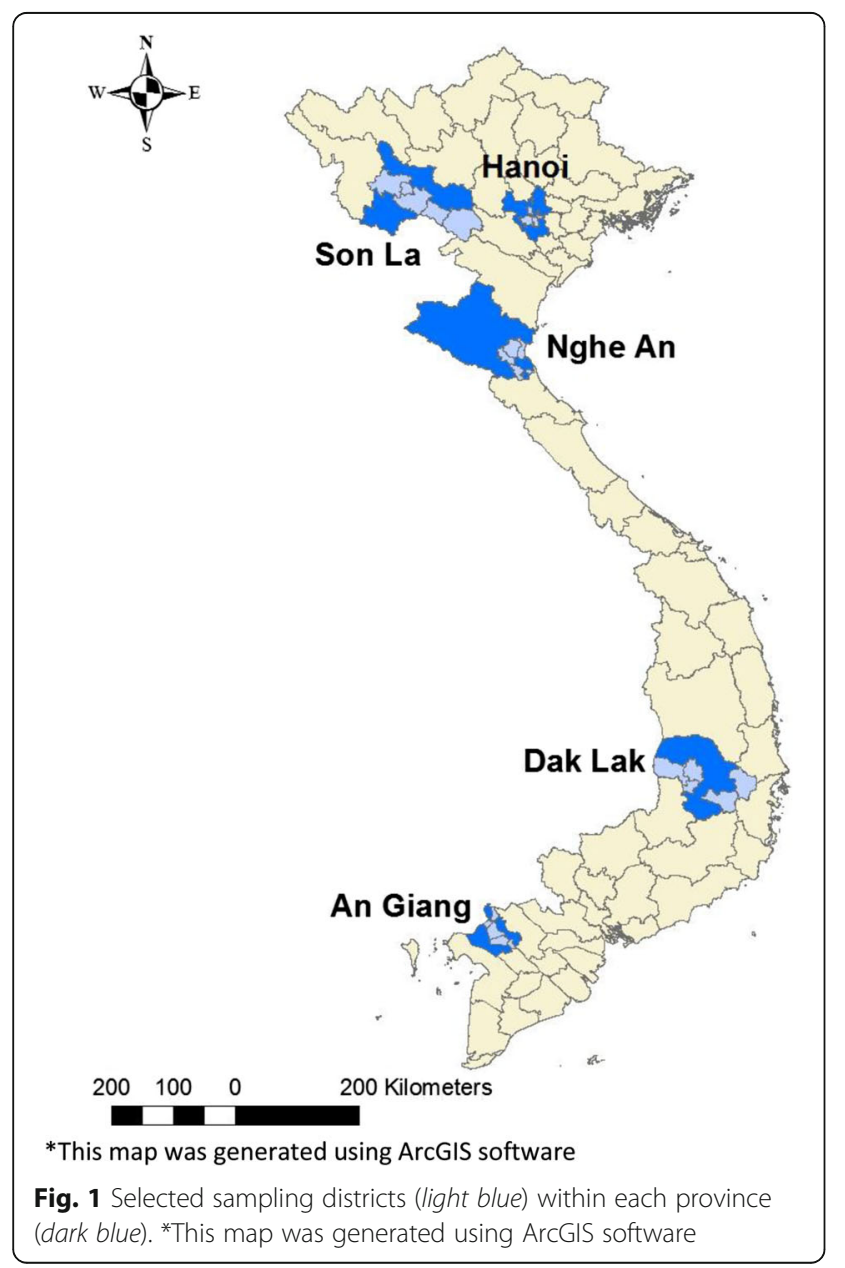

(1.07\%) using a cutoff titer of $\geq 1: 100$ (Table 3). Considering province and serovars Autumnalis, Australis, Grippotyphosa, Javanica and Australis had the highest sero-prevalences in Hanoi, Son La, Nghe An, Dak Lak and An Giang, respectively (Fig. 2). By using a low cutoff titer ( $\geq 1: 100$ ), the percentage of positive MAT results for Leptospira serovars was highest for Tarassovi Mitis (2.20\%) and Australis (1.94\%) (Table 3). A total of 6 samples were positive for two or more serovars: one sample with three serovars (Australis, Grippotyphosa and Javanica) and five samples with two serovars.

The sero-prevalence among female pigs (5.28\%, 95\% CI: 3.94-6.93) was slightly higher than among male pigs $(4.88 \%$, 95\% CI: 3.51-6.58). The logistic regression model showed that there was no statistically significant difference between male and female (Table 4). The Hosmer-Lemeshow goodness of fit test showed that there was evidence of poor fit.

Among positive serovars using a different cutoff [1:100 (no. 167), 1:200 (no. 57), 1:400 (no. 21) and 1:800 (no. 13)], the proportion of serovars Australis (except for 1:800 titer), Grippotyphosa and Icterohaemorrhagiae increased as the cutoff titer increased, whereas it decreased for Autumnalis, Javanica and Tarassovi (Fig. 3).

\section{Discussion}

This large, national study was conducted to assess the sero-prevalence of specific Leptospira serovars in pigs across the country. Overall, the sero-prevalence was lower than reported in previous studies (ranging from 13 to $79 \%$ ) [27-30]. This may be because our samples were collected during the dry and early wet seasons when sero-prevalence is likely to be lower than in the rainy season [31]. Also, most of the previous studies were conducted in the Mekong delta in southern Vietnam that is relatively close to river areas, which might provide more opportunities to come into contact with contaminated water. In addition, samples were collected from slaughterhouses and so represent relatively young animals (pigs age: 6-9 months). One study suggested that older pigs were more likely to be exposed to Leptospira [28]. Moreover, animals sent for slaughter may be less likely to be visibly ill. We found that Tarassovi Mitis, Australis, Javanica, Autumnalis and Grippotyphosa had relatively high positive rates which were similar to those reported by the previous studies [27, 28]. Pigs are considered a reservoir for serovar Tarassovi Mitis which had the highest positive rate in our study, but one study showed that Pomona had the highest rate [32]. Another study found that Bratislava had the highest sero-prevalence among sows in the Mekong Delta of Vietnam, but it was not included in our analysis [28]. Serovars Australis, Grippotyphosa, Tarassovi Mitis were 
Table 2 Sero-prevalence (\%) with 95\% Cl for Leptospira serovars in fattening pigs in Vietnam using MAT

\begin{tabular}{|c|c|c|c|c|}
\hline Province (no.) & District (no.) & $\begin{array}{l}\text { Sero-positive samples } \\
\text { (a titer } \geq 1: 100 \text { for } \\
\text { any serovars) }\end{array}$ & $\begin{array}{l}\text { Sero-positive (\%) with } \\
95 \% \text { Cl (each district) }\end{array}$ & $\begin{array}{l}\text { Sero-positive (\%) with } \\
95 \% \text { Cl (each province) }\end{array}$ \\
\hline \multirow[t]{5}{*}{ Hanoi (390) } & Chuong My (57) & 4 & $7.01(1.94-17.00)$ & $9.49(6.77-12.84)$ \\
\hline & Hoai Duc (56) & 9 & 16.07 (7.62-28.33) & \\
\hline & Thanh Oai (106) & 7 & $6.60(2.70-13.13)$ & \\
\hline & Thanh Tri (90) & 6 & $6.67(2.49-13.95)$ & \\
\hline & Dan Phuong (81) & 11 & $13.58(6.98-23.00)$ & \\
\hline \multirow[t]{5}{*}{ Son La (384) } & Mai Son (77) & 4 & $5.19(1.43-12.77)$ & $7.03(4.68-10.07)$ \\
\hline & Moc Chau (77) & 1 & $1.30(0.03-7.02)$ & \\
\hline & Son La (76) & 2 & $2.63(0.332-9.18)$ & \\
\hline & Thuan Chau (76) & 2 & $2.63(0.332-9.18)$ & \\
\hline & Yen Chau (77) & 18 & $23.38(14.48-34.41)$ & \\
\hline \multirow[t]{5}{*}{ Nghe An (380) } & Dien Chau (73) & 7 & $9.59(3.94-18.76)$ & $8.68(6.05-11.98)$ \\
\hline & Nam Dan (68) & 8 & $11.76(5.22-21.87)$ & \\
\hline & TP. Vinh (95) & 8 & $8.42(3.71-15.92)$ & \\
\hline & Yen Thanh (67) & 3 & $4.48(0.93-12.53)$ & \\
\hline & Do Luong (77) & 7 & $9.09(3.73-17.84)$ & \\
\hline \multirow[t]{5}{*}{ Dak Lak (385) } & Buon Don (81) & 5 & $6.17(2.03-13.82)$ & $7.01(4.67-10.04)$ \\
\hline & Cu Mgar (77) & 3 & $3.90(0.81-10.97)$ & \\
\hline & Krong Bong (67) & 4 & $5.97(1.65-14.59)$ & \\
\hline & M'Drak (79) & 11 & $13.92(7.16-23.55)$ & \\
\hline & Buon Me Thuot (81) & 4 & $4.94(1.36-12.16)$ & \\
\hline \multirow[t]{5}{*}{ An Giang (384) } & Chau Phu (80) & 9 & $11.25(5.28-20.28)$ & $9.38(6.65-12.74)$ \\
\hline & Chau Thanh (85) & 8 & $9.41(4.15-17.71)$ & \\
\hline & Chau Doc (84) & 3 & $3.57(0.74-10.08)$ & \\
\hline & Long Xuyen (83) & 8 & $9.64(4.25-18.11)$ & \\
\hline & Tan Chau (88) & 8 & $9.09(4.01-17.13)$ & \\
\hline Total & 1959 & 160 & $8.17(6.99-9.47)$ & 8.17 (6.99-9.47) \\
\hline
\end{tabular}

Table 3 MAT results for Leptospira serovars in pigs by using 4 cutoff titers during the study period

\begin{tabular}{|c|c|c|c|c|c|c|c|c|c|}
\hline \multirow[t]{2}{*}{$\begin{array}{l}\text { Sero-positive results } \\
\text { Serovar }\end{array}$} & \multirow[t]{2}{*}{ Total tested samples (n) } & \multicolumn{2}{|c|}{$\geq 1: 100$} & \multicolumn{2}{|c|}{$\geq 1: 200$} & \multicolumn{2}{|c|}{$\geq 1: 400$} & \multicolumn{2}{|c|}{$\geq 1: 800$} \\
\hline & & $n$ & $\%(95 \% \mathrm{Cl})$ & $n$ & $\%(95 \% \mathrm{Cl})$ & $n$ & $\%(95 \% \mathrm{Cl})$ & $n$ & $\%(95 \% \mathrm{Cl})$ \\
\hline Tarassovi Mitis & 1959 & 43 & $2.20(1.55-2.84)$ & 11 & $0.56(0.23-0.89)$ & 3 & $0.15(0-0.33)$ & 1 & $0.05(0-0.15)$ \\
\hline Australis & 1959 & 38 & $1.94(1.37-2.65)$ & 16 & $0.82(0.42-1.22)$ & 7 & $0.36(0.09-0.62)$ & 4 & $0.20(0.001-0.40)$ \\
\hline Javanica & 1959 & 33 & $1.68(1.11-2.25)$ & 8 & $0.41(0.13-0.69)$ & 3 & $0.15(0-0.33)$ & 1 & $0.05(0-0.15)$ \\
\hline Autumnalis & 1959 & 23 & $1.17(0.75-1.76)$ & 7 & $0.36(0.09-0.62)$ & 2 & $0.10(0-0.24)$ & 1 & $0.05(0-0.15)$ \\
\hline Grippotyphosa & 1959 & 21 & $1.07(0.62-1.53)$ & 9 & $0.46(0.16-0.76)$ & 4 & $0.20(0.001-0.40)$ & 4 & $0.20(0.001-0.40)$ \\
\hline Canicola & 1959 & 2 & $0.10(0-0.24)$ & 1 & $0.05(0-0.15)$ & 0 & Null & 0 & Null \\
\hline Hebdomadis & 1959 & 2 & $0.10(0-0.24)$ & 1 & $0.05(0-0.15)$ & 0 & Null & 0 & Null \\
\hline Icterohaemorrhagiae & 1959 & 2 & $0.10(0-0.24)$ & 2 & $0.10(0-0.24)$ & 2 & $0.10(0-0.24)$ & 1 & $0.05(0-0.15)$ \\
\hline Hardjo & 1959 & 1 & $0.05(0-0.15)$ & 1 & $0.05(0-0.15)$ & 0 & Null & 0 & Null \\
\hline
\end{tabular}




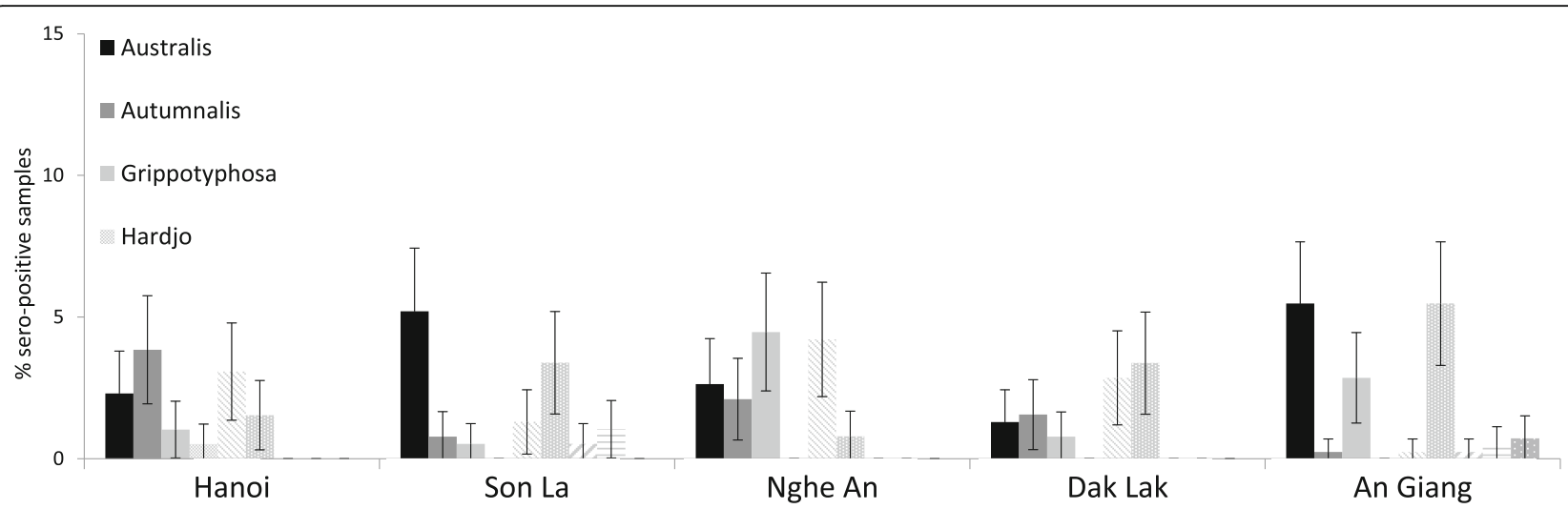

Fig. 2 Percentage with 95\% confidence interval of sero-positive samples by serovar in each province using cutoff titer $\geq 1: 100$

detected in our study, and other studies also found these serovars in wild boars [33-35]. In France, a re-emergence of brucellosis in outdoor pigs was linked to contact with wild boars [36]. It is possible that wild boars may play an important role in the transmission of leptospirosis to domesticated pigs in Vietnam. In addition, we detected serovars Javanica and Icterohaemorrhagiae, implying that rats may have infected pigs [19]. Other studies found that increased movement of wild animals during fall and early winter, associated with seeking shelter and food for the winter season, increases contact with domestic animals or organisms shed by wild animals [35, 37]. Further investigations are required to better understand the role of wildlife in transmission of leptospirosis in Vietnam.

Leptospirosis in humans is a notifiable disease in Vietnam (one of 28 notifiable diseases) that should be reported to the preventive medicine networks. However, due to lack of medical facilities and public awareness, few human cases have been reported in Vietnam. Only 48 cases were officially reported between 2008 and 2013 (annual incidence rate: 0.011 per 100,000$)$. Surveys typically find higher levels; one study conducted in Tien Giang (Mekong Delta region) found a sero-prevalence of $18.8 \%$ among 1400 and the most prevalent serovars were Bataviae, Panama, Icterohaemorrhagiae and Australis [24]. A serological study conducted among children in southern Vietnam in 2003 reported a sero-prevalence of $12.8 \%$ [25].

Leptospirosis is considered an occupational risk for agriculture workers, mining workers, sewer maintenance

Table 4 Logistic regression model of leptospirosis with random effect (positive was considered if cutoff titer $\geq 1: 100$ )

\begin{tabular}{lllll}
\hline Variable & Category & Adjusted Odds ratio & $95 \% \mathrm{Cl}$ & $P$-value \\
\hline Sex & Female & Reference & N/A & N/A \\
& Male & 1.09 & $0.77-1.55$ & 0.624 \\
\hline
\end{tabular}

$\mathrm{Cl}$ confidence interval, NA not applicable as reference group workers, veterinarians and other individuals who are likely to come into contact with contaminated water or soil and infected animals [4].

Serovars Autumnalis, Australis, Grippotyphosa and Javanica have been recognized as major causes of human leptospirosis in Asian countries, and were detected in our study. It is possible that the disease could be transmitted from pigs to humans [20, 38, 39]. In Vietnam, small-scale pig production accounts for $80 \%$ of the total production, providing opportunities for transmission from pigs to farmers and their families [40]. In the United States of America, an epidemiological study showed that swine producers and slaughterhouse workers had relatively higher sero-prevalence of leptospirosis in comparison with other occupational groups [41]. In Mexico, keeping domestic livestock (cattle and pigs) significantly increased the odds of disease in a rural community [42]. Therefore, swine sero-prevalence may be useful as a surrogate marker of the human/animal leptospirosis incidence in Vietnam. Additional studies could evaluate the sero-prevalence in agricultural farmers and butchers as well as identifying the modes of transmission and potential risk factors through surveys of farm workers.

In particular, potential environmental risk factors (such as climate factors, rural or urban status and proximity to lakes and rivers) should be evaluated. Previous studies showed a seasonal pattern and a positive association with the amount of rainfall [31, 36, 43]. In Vietnam, there are two distinct seasons: dry (from January to May) and wet (from June to December). It could be possible that outbreaks of leptospirosis are more likely to occur during the wet season in Vietnam. Therefore, strengthened monitoring and surveillance systems are needed to better understand the epidemiology of leptospirosis and prevent or reduce infection in humans and animals. 


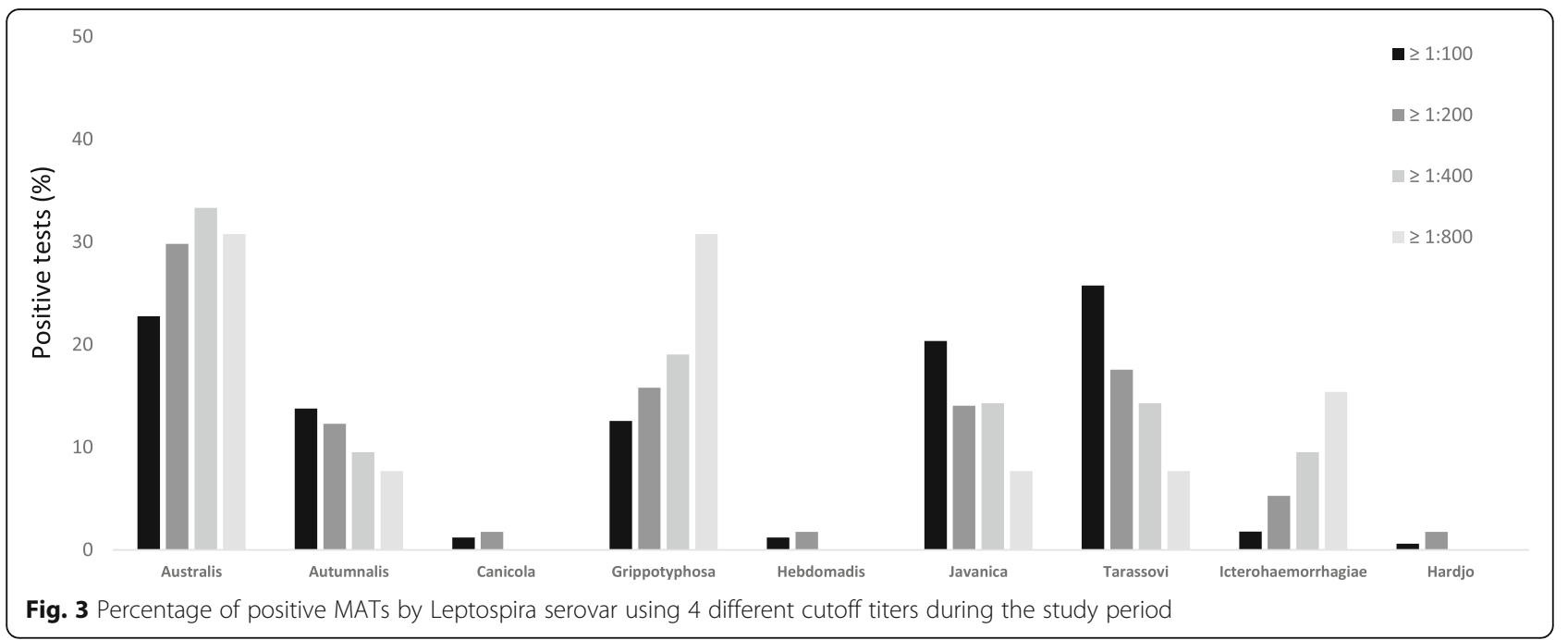

\section{Conclusion}

Leptospirosis in pigs may be a useful indicator of the human/animal burden in Vietnam and a risk assessment tool. These studies are a way of providing evidence to veterinarians on diagnosis, vaccination and control of zoonotic pathogens. In addition, the presence of some of the identified serovars suggests that wildlife may play an important role in the transmission of leptospirosis to domesticated pigs in Vietnam. Further investigation is needed in each region into the possible role of different wildlife species or environmental conditions in contributing to infection.

\section{Abbreviations}

Cl: Confidence interval; MAT: Microscopic agglutination test; NIVR: National institute of veterinary research

\section{Acknowledgments}

We would like to thank the National Institute of Veterinary Research under the Ministry of Agriculture and Rural Development in Vietnam for supporting sample collection and analysis on leptospirosis.

\section{Funding}

We acknowledge the CGIAR Fund Council, the Australian Centre for International Agricultural Research, Irish Aid, the European Union, the International Fund for Agricultural Development, Netherlands, New Zealand, Switzerland, the United Kingdom, the United States Agency for International Development and Thailand for funding to the CGIAR Research Program on Climate Change, Agriculture and Food Security.

\section{Availability of data and materials}

All datasets supporting our findings are available from the corresponding author on reasonable request.

\section{Authors' contributions}

Conceived and designed the experiments: HSL, HNV and DG. Performed the experiments: HSL, NVK, HNX and VBN Analyzed the data: HSL, HNX and VBN. Wrote the paper: HSL, HNV and DG. All authors read and approved the final manuscript.

\section{Competing interests}

The authors declare that they have no competing interests.
Consent for publication

Not applicable.

Ethics approval and consent to participate

The study was approved by the Hanoi Medical University Institutional Review Board (HMU IRB: no. 00003121), Vietnam. Consent was verbally approved by slaughterhouse owners to collect all of the samples.

\section{Publisher's Note}

Springer Nature remains neutral with regard to jurisdictional claims in published maps and institutional affiliations.

\section{Author details}

${ }^{1}$ International Livestock Research Institute, Regional Office for East and Southeast Asia, Room 301-302, B1 Building, Van Phuc Diplomatic Compound, 298 Kim Ma Street, Ba Dinh District, Hanoi, Vietnam. ${ }^{2}$ National Institute of Veterinary Research, 86 Truong Chinh, Phuong Mai, Dong Da, Hanoi,

Vietnam. ${ }^{3}$ International Livestock Research Institute, Nairobi, Kenya.

Received: 15 November 2016 Accepted: 3 May 2017

Published online: 08 May 2017

\section{References}

1. Alston JM, Broom JC, Doughty C. Leptospirosis in men and animals. Edinburgh: E\&S Livingstone; 1958.

2. Faine S. Leptospira and leptospirosis. Boca Raton: CRC Press Inc; 1994.

3. Pappas G, Papadimitriou P, Siozopoulou V, Christou L, Akritidis N. The globalization of leptospirosis: worldwide incidence trends. Int J Infect Dis. 2008;12:351-7.

4. Bharti AR, Nally JE, Ricaldi JN, Matthias MA, Diaz MM, Lovett MA, Levett PN, Gilman RH, Willig MR, Gotuzzo E. Leptospirosis: a zoonotic disease of global importance. Lancet Infect Dis. 2003;3:757-71.

5. Levett PN, Haake DA. Leptospira species (leptospirosis), Mandell, Douglas and Bennett's principles and practice of infectious diseases. 7th ed. Philadelphia: Churchill-Livingstone; 2010. p. 3059-4005.

6. Hanson L. Leptospirosis in domestic animals: the public health perspective. J Am Vet Med Assoc. 1982;181:1505-9.

7. Heisey G, Nimmanitya S, Karnchanachetanee C, Tingpalapong M, Samransamruajkit S, Hansukjariya P, Elwell M, Ward G. Epidemiology and characterization of leptospirosis at an urban and provincial site in Thailand. Southeast Asian J Trop Med Public Health. 1988;19:317-22.

8. Bolin CA (1996) Diagnosis of leptospirosis: a reemerging disease of companion animals, Seminars in veterinary medicine and surgery (small animal).

9. Brown CA, Roberts AW, Miller M, Davis D, Brown SA, Bolin CA, Jarecki-Black J, Greene C, Miller-Liebl D. Leptospira interrogans serovar grippotyphosa infection in dogs. J Am Vet Med Assoc. 1996;209:1265-7. 
10. Ayanegui-Alcerreca M, Wilson P, Mackintosh C, Collins-Emerson J, Heuer C, Midwinter A, Castillo-Alcala F. Leptospirosis in farmed deer in New Zealand: a review. N Z Vet J. 2007;55:102-8.

11. Ellis WA. Leptospirosis as a cause of reproductive failure. Vet Clin North Am Food Anim Pract. 1994;10:463-78.

12. Van Til LD, Dohoo IR. A serological survey of leptospirosis in Prince Edward Island swine herds and its association with infertility. Can J Vet Res. 1991;55: 352-5.

13. Baker TF, McEwen SA, Prescott JF, Meek AH. The prevalence of leptospirosis and its association with multifocal interstitial nephritis in swine at slaughter. Can J Vet Res. 1989;53:290-4.

14. Hathaway S, Little T. Prevalence and clinical significance of leptospiral antibodies in pigs in England. Vet Rec. 1981;108:224-8.

15. Ellis WA, Montgomery JM, Thiermann AB. Restriction endonuclease analysis as a taxonomic tool in the study of pig isolates belonging to the Australis serogroup of Leptospira interrogans. J Clin Microbiol. 1991;29:957-61.

16. Bolin CA, Cassells JA, Hill HT, Frantz JC, Nielsen JN. Reproductive failure associated with Leptospira interrogans serovar bratislava infection of swine. J Vet Diagn Investig. 1991;3:152-4.

17. Ellis W, McParland P, Bryson D, Cassells J. Prevalence of Leptospira infection in aborted pigs in Northern Ireland. Vet Rec. 1986;118:63-5.

18. Ryan T, Marshall R. Isolation of a leptospire belonging to serogroup tarassovi. N Z Vet J. 1976:24:212-3.

19. Loan HK, Van Cuong N, Takhampunya R, Kiet BT, Campbell J, Them LN, Bryant JE, Tippayachai B, Van Hoang N, Morand S. How important are rats as vectors of leptospirosis in the Mekong Delta of Vietnam? Vector Borne Zoonotic Dis. 2015;15:56-64.

20. Vaucel M. Le serodiagnostic de Martin et Pettit au Tonkin. Resultats de 800 sero-agglutinations. Bull Soc Patholog Exot. 1936;29:251-7.

21. Sejvar J, Tangkanakul W, Ratanasang P, Dowell SF. An outbreak of leptospirosis, Thailand-the importance of the laboratory. Southeast Asian J Trop Med Public Health. 2005;36:289-95.

22. Laras K, Cao BV, Bounlu K, Nguyen TK, Olson JG, Thongchanh S, Tran NV, Hoang KL, Punjabi N, Ha BK, Ung SA, Insisiengmay S, Watts DM, Beecham HJ, Corwin AL. The importance of leptospirosis in Southeast Asia. AmJTrop Med Hyg. 2002;67:278-86.

23. Berman SJ, Tsai CC, Holmes K, Fresh JW, Watten RH. Sporadic anicteric leptospirosis in South Vietnam: a study in 150 patients. Ann Intern Med. 1973;79:167-73.

24. Van CT, Thuy NT, San NH, Hien $\Pi$, Baranton G, Perolat P. Human leptospirosis in the Mekong delta, Viet Nam. Trans R Soc Trop Med Hyg. 1998:92:625-28

25. Thai KT, Binh TQ, Giao PT, Phuong HL, Hungle Q, Van Nam N, Nga TT, Goris $M G$, de Vries PJ. Seroepidemiology of leptospirosis in southern Vietnamese children. Tropical Med Int Health. 2006;11:738-45.

26. Hosmer DW, Hosmer T, Le Cessie S, Lemeshow S. A comparison of goodnessof-fit tests for the logistic regression model. Stat Med. 1997;16:965-80.

27. Boqvist S, Montgomery JM, Hurst M, Thu HT, Engvall EO, Gunnarsson A, Magnusson U. Leptospira in slaughtered fattening pigs in southern Vietnam: presence of the bacteria in the kidneys and association with morphological findings. Vet Microbiol. 2003;93:361-8.

28. Boqvist S, Chau BL, Gunnarsson A, Olsson Engvall E, Vågsholm I, Magnusson $U$. Animal-and herd-level risk factors for leptospiral seropositivity among sows in the Mekong delta, Vietnam. Prev Vet Med. 2002;53:233-45.

29. Thu HTV, Hieu TC (2002) Prevalence of Leptospira in pigs in Tan Phu Thanh village. Research topics of livestock production.

30. Cao V, Dang-Trinh MA, Alonso S, Gilbert J, Lapar M, Khang DN, Van Hiep M (2014) Leptospira spp. serogroups identification in human and pig serum samples from two provinces in Vietnam. Poster.

31. Sethi S, Sharma N, Kakkar N, Taneja J, Chatterjee SS, Banga SS, Sharma M. Increasing trends of leptospirosis in northern India: a clinico-epidemiological study. PLoS Negl Trop Dis. 2010;4:e579.

32. Mason RJ, Fleming PJS, Smythe LD, Dohnt MF, Norris MA, Symonds ML. Leptospira interrogans antibodies in feral pigs from New South Wales. Wilddi Dis. 1998;34:738-43.

33. Hartskeerl PA, Terpstra WJ. Leptospirosis in wild animals. Vet Q. 1996;18:149-50

34. Kmety E. Leptospirosenherde in der Slowakei. Zentralbl Bakt. 1955;163:464-76.

35. Feldhamer GA, Thompson BC, Chapman JA. Wild mammals of North America: biology, management, and conservation. USA: JHU Press; 2003.
36. Kim SH, Jang JY. Correlations between climate change-related infectious diseases and meteorological factors in Korea. J Prev Med Public Health. 2010;43:436-44.

37. Bixler A, Gittleman JL. Variation in home range and use of habitat in the striped skunk (Mephitis mephitis). J Zool. 2000;251:525-33.

38. Seng H, Sok T, Tangkanakul W, Petkanchanapong W, Kositanont U, Sareth $H_{\text {, }}$ Hor B, Jiraphongsa C. Leptospirosis in Takeo Province, Kingdom of Cambodia. J Med Assoc Thail. 2007;90:546-51.

39. Victoriano AF, Smythe LD, Gloriani-Barzaga N, Cavinta LL, Kasai T, Limpakarnjanarat K, Ong BL, Gongal G, Hall J, Coulombe CA. Leptospirosis in the Asia Pacific region. BMC Infect Dis. 2009:9:147.

40. MLA Lapar, Vu TB, Ehui S 2003 Identifying barriers to entry to livestock input and output markets in South-East Asia: the case of Vietnam, ILRI (aka ILCA and ILRAD).

41. Campagnolo ER, Warwick MC, Marx HL Jr, Cowart RP, Donnell HD Jr, Bajani MD, Bragg SL, Esteban JE, Alt DP, Tappero JW, Bolin CA, Ashford DA. Analysis of the 1998 outbreak of leptospirosis in Missouri in humans exposed to infected swine. J Am Vet Med Assoc. 2000;216:676-82.

42. Leal-Castellanos CB, García-Suárez R, González-Figueroa E, Fuentes-Allen JL, Escobedo-de la Peñal J. Risk factors and the prevalence of leptospirosis infection in a rural community of Chiapas, Mexico. Epidemiol Infect. 2003; 131:1149-56.

43. Romero EC, Bernardo CC, Yasuda PH. Human leptospirosis: a twenty-nineyear serological study in São Paulo, Brazil. Rev Inst Med Trop Sao Paulo. $2003 ; 45: 245-8$.

\section{Submit your next manuscript to BioMed Central and we will help you at every step:}

- We accept pre-submission inquiries

- Our selector tool helps you to find the most relevant journal

- We provide round the clock customer support

- Convenient online submission

- Thorough peer review

- Inclusion in PubMed and all major indexing services

- Maximum visibility for your research

Submit your manuscript at www.biomedcentral.com/submit 